\title{
CSENDES ISTVÁN
}

\section{ELMÉLETI FELVETÉSEK ÉS GYAKORLATI TAPASZTALATOK A PROJEKTPORTFÓLIÓ- MENEDZSMENT HAZAI MEGJELENÉSE KAPCSÁN}

A projektportfólió-menedzsment (PPM) abban a helyzetben válik elengedhetetlenül fontossá, amikor több projekt egyidejű megvalósításából fakadó problémákkal kell szembenézni. Miközben a projektekben történő gondolkodás számos területen egyre jellemzőbb, fel kell tenni azt a kérdést is, hogy a sok projekt együtt vajon optimális rendszert alkot-e az adott szervezetben, és megfelelően támogatja-e a versenyképességet, az erőforrások optimális felhasználását, a szervezet céljait?

A szervezetek vezetői már ráeszméltek erre a dilemmára, és a PPM-et egyre inkább alkalmazzák cégeik/intézményeik működési hatékonyságának javítására. A következőkben a szerző arra tesz kísérletet, hogy ennek az új stratégiai menedzsmenteszköznek a hazai megjelenése kapcsán, felvillantsa a téma elméleti hátterét, illetve gyakorlati használhatóságát. Mindezt úgy teszi, hogy külön hangsúlyt fektet a módszer magyarországi megjelenésének konkrét tapasztalataira is.

Kulcsszavak: projektportfólió-menedzsment, stratégiai menedzsment, projektmenedzsment, bankszektor, kvalitatív interjúk

A projektportfólió-menedzsmentnek nincs túl hosszú története Magyarországon. Valójában még a gyakorlati-közgazdász szakma is csak most ismerkedik a fogalommal. Egyrészt a témával foglalkozó magyar nyelvü tudományos közlemény - vagy az elmélet szempontjából érdemleges publikáció - is csak egy-egy jegyezhető fel. Másrészt viszont az elmúlt időszakban egyre több magyarországi székhelyü vagy telephelyü szervezet kezdett el projektportfólió-menedzsmenttel (PPM) foglalkozni. Egyelőre ezt csak a szervezetek vezetőinek és munkatársainak beszámolóiból vagy olykor-olykor megjelenő szakértői előadásokból tudhatjuk. Persze „laikusként” az is feltünhet bárkinek, hogy a cégek egyre több helyen foglalkoztatnak, vagy éppen keresnek projektportfólió-menedzsereket.

Szokásos helyzet ez, hiszen miközben a magyar gyakorlat némi fáziskéséssel, de követi a nyugati trendeket, a hazai elméleti feldolgozás még elmaradásban van. Hiszen míg nemzetközi szinten a projekt- és a stratégiai menedzsment tudósai, a különböző szakmai szervezetek képviselői, illetve a nagyvállalati szakértők egy ideje már foglalkoznak a témával, addig Magyarországon a nagyon szük - gyakorlatközeli - szakmai berkeken kívül, nem kapott még igazi publicitást ez a terület. Ebből kifolyólag nem beszélhetünk még egy kialakult PPM-szakmáról sem, inkább csak arról, hogy szemünk előtt formálódik ez az új szakterület. Ebben a helyzetben, én magam a következőkben, néhány pontban kifejtem a PPM-mel kapcsolatos legfontosabb tudnivalókat: a koncepciótól, a módszertani ajánlásokon át, a magyarországi megjelenésének első tapasztalataiig.

A továbbiakban röviden rávilágítok témánk hazai tudományos megjelenésére, illetve projekt- és stratégiai menedzsment vonatkozásaira, majd a PPM-et olyan koncepcióként mutatom be, mint amely alapvető vállalatgazdasági, vállalatstratégiai feladatokra reflektál. Itt az elérhető módszertani ajánlásokra is kitérek majd. Ezután nemzetközi felmérések alapján felvillantom az új me- nedzsmenteljárás megjelenésének általános tapasztalatait. Végül a PPM hazai megjelenéséről írok a magyar bankszektor néhány kiemelt szereplőjének elmúlt évekbeli tapasztalatait felhasználva.

\section{Az új menedzsmentmódszerről és a hazai tudományos előzményekről}

A projektportfólió-menedzsment hazai tudományos megjelenése nem mondaható átütőnek. Mégis, megjelentek már a módszerrel foglalkozó írások, szóbeli közlések. Ezek különböző mélységben tárgyalják a témát. A kérdés egyik tipikus megjelenése a projektvezetés témában írt szakkönyvekben lelhető fel. A Magyarországon is ismert szerzők magyar nyelvű írásai közül, például, amíg Sebes (2013) könyvében csak megemlíti, addig Görög (2013) kötete már egy egész oldalban foglalkozik a témával, míg az ismert osztrák szerző, Gareis (2007), egy egész fejezetet szentel ennek a kérdéskörnek.

Más a helyzet a különböző szakmai szervezetek által szervezett eseményekkel, ahol a téma időről időre fel-feltünik. Ilyen kiemelt esemény volt pl. a 2015-ben a HTE által rendezett 18. Projektmenedzsment Fórum, amely kiemelt témaként kezelte a projektportfólió-menedzsmentet. Ezeken a rendezvényeken a téma szakértői, illetve vezető gyakorlati szakemberek már beszámoltak koncepcióikról, tapasztalataikról.

A jegyzett tudományos közleményekben (MTMT) már kevesebb referenciapontot találunk. Magyar nyelven Sebestyén Zoltán 2009-es, a Vezetéstudományban megjelent cikkében vezeti be a témát (Sebestyén, 2009). A későbbiek során, szerzőtárssal kiegészülve, szintén ő publikál a témában (Sebestyén - Tóth, 2012). Rajta kívül a szintén két közleményt jegyző Ligetvári Évát (Ligetvári, 2012, 2013) lehet még megemlíteni, mint a témában publikáló szerzőt.

Néhány alapkérdésben érdemes (pl. a definíció és a menedzsmentterület kialakulásának főbb trendjei) Sebestyén 2009-es cikkére támaszkodni. Ebből a cikkből, de 
más szakirodalomból (pl. Levine, 2005) is tudjuk, hogy számos szerző definiálta már a PPM-et. Sebestyén, más szerzőkkel egyetemben, általános definíciót hoz. Ezek a „holisztikus” felfogású definíciók tág teret biztosítanak a gyakorlatban a PPM-et használók számára, hogy saját megoldásaikat PPM-megoldásként kezeljék. Ezért elfogadhatónak tartom a PPM tevékenységrészletező vagy -értelmező definiálása helyett azokat, amelyek a PPM-et egyféle speciális menedzsmenteljárásnak tekintik. Ilyen módón jól használható a Sebestyén-féle definíció is, amely szerint a „PPM több projekt, program és egyéb - akár portfólión kívüli - a vállalat stratégiai céljai érdekében rangsorolt tevékenységek halmazának hatékony menedzsmentje". Hozzáteszem, hogy csakis a témakör (ebben a cikkben is megragadható) normatív tárgyalása miatt tartom megengedhetőnek a „hatékony” kifejezés használatát a definícióban.

Az új menedzsmentterület kialakulásának főbb trendjeivel kapcsolatosan Sebestyén (2009) a Devinney - Stewart (1988) és a Blichfeldt - Eskerod (2008) szerzőpárosokra hivatkozva kifejti, hogy pénzügyi gyökereinek köszönhetően kezdetben a PPM a hozamkockázat kettősén alapult. Majd az optimális projektszámot meghatározó matematikai módszerek alkalmazása után, mára kifinomult kritériumrendszerek (pl. nem pénzügyi szempontok megjelenése) jellemzik a módszert.

\section{A projektmenedzsmenttől a stratégiai menedzsmentig}

A PPM természetszerüleg szervesen kapcsolódik a projektmenedzsmenthez (PM), mégis hiba lenne kizárólag ez utóbbi továbbfejlődéseként, kiterjeszkedéseként értelmezni, hiszen alapfelfogása nem pusztán a PM-re jellemző munkatervezési, -szervezési és -monitoring feladatokra terjed ki, hanem bátran alkalmazható a legmagasabb szintü vállalatvezetés számára is. Hiszen, valójában a stratégia megvalósításának feladatáról beszélünk, amelyet a felső vezetésnek, szerencsés esetben, szervezetileg támogatottan a stratégiai menedzsmentnek kell felvállalnia. A stratégiai menedzsment alapgondolatához nagyon könnyen társítható a PPM, leegyszerüsítve ugyanis arról van szó, hogy a szervezet egyrészről diagnosztizál, másrészről cselekszik. A stratégiai menedzsment gondolkodásmódjában sokféleképpen megjelenik ez a kettősség (pl. a stratégiaalkotás vs. stratégiamegvalósítás fogalmaival). Könnyü belátni, hogy a projektek, amelyek a változást jelentik a szervezetek életében, valójában végső soron megtestesítik a „stratégiai” cselekvést. Ezen túl normatív értelemben, a jövőre irányuló változásokat (néha nagyszámú projekt formájában), a cél(ok) elérésének az érdekében tudatosan és hatékonyan kell menedzselni. Ennek lehetőségét kínálja a felső vezetés számára a projektportfólió-menedzsment. ${ }^{1}$

A sok projekt együttes kezelése természetesen megköveteli a projektmenedzsment operatív felfogását is, de ezt inkább a multiprojekt-menedzsment látja el, amelyet a legmagasabb szintü projektorientációjú menedzsmenttevékenység, a PPM felügyel.
A PPM definíció szerint is a stratégiai menedzsment „magas szintü” értékteremtési kérdéskörére a stratégia/ hozam/hatékonyság problematikájára koncentrál. E felfogás szerint, mivel a PPM a célok operacionalizálásának eszköze, ezért a szervezet működése nyilvánvalóan nagyban függ töle. Továbbá, amennyiben ily módón a stratégia megvalósitásának az eszköze, nyilvánvalóan elementáris érdekek megtestesítője is. Nemcsak a jövőorientált vállalati müködés hatékonyságának a záloga, hanem a megszerezhető előnyök (sőt a pénzügyileg is mérhető nyereség) elérésének a fegyvere is. Így központi szerepe van a stratégiai és pénzügyi törekvések megvalósításában. A projektekbe történő befektetés ugyanis természetszerüleg sok esetben akár pusztán pénzügyi befektetésként is értelmezhető (Zdanyte - Neverauskas, 2011), ahol a profitérdek nyilvánvaló, az előnyök és hozamok mérése alapvető. A hozam maximalizálása legtöbb esetben elvárt. Ezeknek a céloknak az elérése azonban nem triviális feladat, komoly menedzsmentkihívást jelent. Nem csoda hát, hogy az egyes vállalati PPM-megoldások esetén fontos szerep jut az előzetes portfólióértékelő modelleknek, vagy akár csak a különböző szempontok együttes érvényesülésének (pl. stratégiai, pénzügyi, jogi, kockázatokkal kapcsolatos stb.). Ez erős tervezési, monitoring és pénzügymódszertani jelleget biztosít a vizsgált stratégiai-szervezési témakörnek. ${ }^{2}$

\section{A PPM koncepciója és módszertana}

Az eddigiekkel jutottunk el igazából a PPM alapproblémájához, amelyet itt elsődlegesen egy fontos vállalatgazdasági és stratégiai kérdésként értelmezek. Nevezetesen: a szervezetben zajló cselekvések, amelyek akár a rutinszerü, akár a projektszerü müködéshez kapcsolódnak, a maguk erőforrásaiért küzdenek. Ezek az erőforrások még a ,,jobb időkben” is szükösek, nemhogy a válságokkal, a hiányokkal jellemezhető időszakokban. A PPM szerepe ebben az összefüggésben értelmezhetö a legjobban, hiszen a szervezet nem-rutinszerü működéséhez kapcsolódó tevékenységek esetén elemi fontosságú képesség: a legna-

1. ábra

\section{A portfóliómenedzsment szervezeti kontextusa}

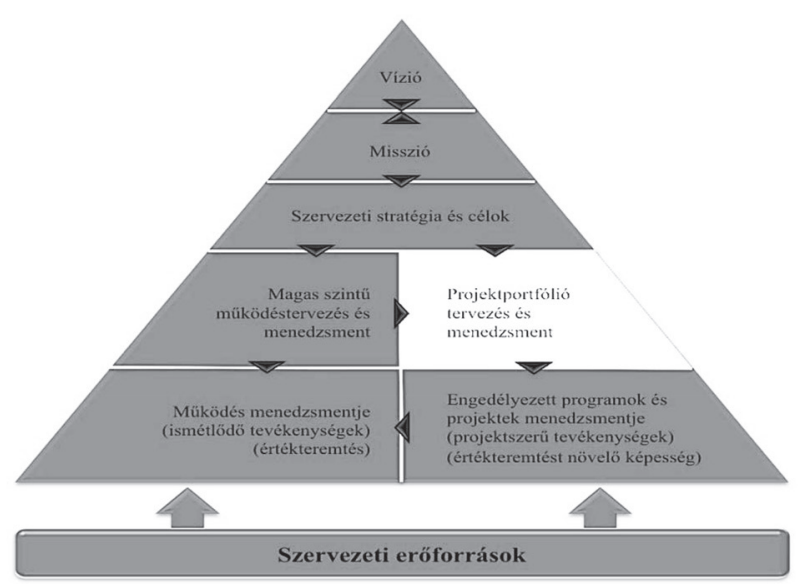

Forrás: PMI: Projektportfólió-menedzsment (2011) 
gyobb előnyt hozó projektek beazonosítása, majd további kezelése. Ebben a kontextusban jól értelmezhető a $P P M$ központi szerepe. Az 1. ábra ezt az integráló szerepet mutatja be.

Ebben a feladatában számos kihívás éri a szervezetet. Ezek a kihívások alapvetően a projektportfólió természetéből adódnak, hiszen a portfólió nem más, mint a konkurens, párhuzamosan futó és a szükös erőforrásokért versengő egyedi projektek (esetleg programok) gyüjteménye. A projektportfólió különböző menedzsmentkövetelményei így eltérnek az egyedi óriás projektek (és programok) menedzsmentkövetelményeitöl. Itt ugyanis az elsődleges kihívás az, hogy a portfólió komponenseinek (projekteknek), folyamatosan meg kell egymással birkózniuk a cég korlátozott erőforrásaiért vívott küzdelemben (Chao - Kavadias, 2008; Dye - Pennypacker, 1999). Egy másik kritikus kihívás, hogy a szervezeteknek dinamikus környezetben kell tevékenykedniük (Petit - Hobbs, 2010), amelyben a projektek száma, összetétele és kölcsönös függöségük folyamatosan változik, ahogyan a portfólió is a szervezet kontextusában (pl. vállalati stratégia, szervezeti struktúra és felső vezetés). Így a PPM nem pusztán az erőforrások allokációjának eszköze, feladata sokkal inkább a projektek portfólióba történő befogadása, az egyedi projektek elörehaladásának monitorozása és valamenynyi, a portfólióban lévő projekt folyamatos rangsorolása. Mindez a tevékenység az egyensúly, a szinergiák és a siker elérésének az érdekében történik, miközben a projektportfólió a cég stratégiájának elsődleges terepeként tünik föl (Morris - Jamieson, 2005). A PPM-et így akár felfoghatjuk egy olyan üzleti folyamatnak is, amelynek fó feladata az egymással kölcsönhatásban lévö összetett folyamatok egységes irányitása, segítve ezzel a döntéshozókat (az értékelésben, kiválasztásban, rangsorolásban stb.) akik a szervezet más tagjaival együtt - alapvetően a hasznok realizálásában és az eredmények visszacsatolásában érdekeltek.

Ezeket a folyamatokat a projektportfólió-menedzsment iroda (közkeletű angol rövidítéssel PPMO) irányítja. Ezek az irodák hatáskörük-feladatvállalásuk alapján nagyban különböznek egymástól. A projektportfólió-menedzsment iroda (PPMO) feladata a projektmenedzsment irodát (közkeletü angol rövidítéssel PMO) túlszárnyalva már nemcsak a projektek és programok leszállítása, hanem a befektetések optimalizálása a szervezet stratégiai céljainak elérése érdekében, továbbá szorosabb kapcsolatban áll a vezérigazgatókkal és projekt- és programfelelösökkel. Hozzáadott értékét adja a PMO-hoz képest a keresztfunkcionális szinergia pozitív hatásának megjelenése. Mindezek következtében kiterjedése sokkal szélesebb, összvállalati szintű is lehet. A szervezeti sikerhez való hozzájárulás módja alapján több típusát is megkülönböztethetjük. Így a jelentési, stratégiai, müködési és üzleti folyamat átalakító PPMO-k egymást kiegészítve, együttesen képesek a legszélesebb körü igényeket kielégíteni. Míg a jelentési PPMO biztosítja, hogy a megfelelő információkat használják fel a döntéshozók, addig a müködési PPMO segíti a programok és projektek megfelelő módon való megvalósulását. A stratégiai PPMO támogatja a szervezet abban, hogy a megfelelő programokat és projekteket válasszák ki. A PPMO negyedik típusa a szervezeti változások kivitelezésében segít (Rouwendaal et al., 2014; Unger et al., 2012).

Különböző mértékben, de mindegyikben közös a koordináló, kontrolláló és támogató szerep, melyek elősegítik az erőforrás-allokáció nagyobb hatékonyságát, a transzparencia javulását, az információk megbízhatóságának növekedését és a szélesebb körü tudásátadást, kommunikációt (Rouwendaal et al., 2014; Unger et al., 2012).

A szervezeti leképeződésen túllépve, Beringer és kutatótársai felmérése alapján a PPM sikerességére két belsö érintetti csoport gyakorolja a legnagyobb hatást: a funkcionális vezetők és a projektmenedzserek. Utóbbiak szerepének fontossága egyértelmü, hiszen ők közvetlenül felelősek a projektek végrehajtásáért. Mindemellett a funkcionális vezetők teremtik meg a kapcsolatot a működési területek és a stratégia között, továbbá ők biztosítják a projektportfólióhoz szükséges erőforrásokat, a területükhöz tartozó szaktudást, valamint kellö szervezeti, politikai befolyással bírnak a projektek támogatásához vagy ellenzéséhez (Beringer et al., 2013). Ugyanakkor mind a gyakorlatban, mind a szakirodalomban megjelenik egy új, prominens szereplő: a projektportfólió-menedzser. Jonas (2010), aki kiemelhető a formális projektportfólió-menedzser szerepkörének leírása kapcsán, azt javasolja a több-projektes PMO-k részére, hogy váljanak projektportfólió-menedzserekké, egyféle központtá, amely a meglévő speciális portfólióismerettel, a felső vezetés támogatója lehet.

Az alapkoncepció és a föbb szervezeti egységek és szereplök felvázolása után ezen a ponton röviden ki kell térnem a PPM-módszertanok kérdésére is. A feladatok (értékelés, kiválasztás stb.) kezelésére a gyakorlatban a vállalatok leginkább egyéni megoldásokkal kísérleteznek. Mégis meg kell említeni, hogy mára már elérhető néhány módszertani ajánlás vagy szabvány, amely iránymutató lehet, a szervezetek számára. Ezek közül kiemelhető az ISO 21504 és a Project Management Institute (PMI) PPM kiadványa, de ismertek más, pl. brit és ausztrál útmutatók/ módszertanok is. ${ }^{3}$

A legismertebb PMI „szabványa” szerint a PPM két folyamatcsoportra (besorolási, követési és felügyeleti) és két folyamat-tudásterületre (portfólióirányítás, porfóliókockázat-menedzsment) osztható (PMI, 2011; PMI, 2013). A besorolási folyamatcsoport biztosítja a vonatkozó információk rendelkezésre állását és a portfólió elemeinek kiértékelésére, a portfólió felépítésére vonatkozó operatív szabályokat, valamint a portfólió elemeinek a szervezeti stratégiához való illesztettségét. A követési és felügyeleti folyamatcsoportba tartozó tevékenységek a szervezet által elöre meghatározott feltételek, mutatók, teljesítményértékek elérésének irányítását jelentik a portfólió, mint egész müködése szempontjából. A projektportfólió-menedzsment folyamat lépései így a következők: komponensazonosítás, komponenskategorizálás, komponensértékelés, komponenskiválasztás, komponens-rangsorolás ${ }^{4}$, portfólió-kiegyensúlyozás, komponensengedélyezés, portfólióteljesítmény-felülvizsgálat és jelentés, az üzleti stratégia változásának követése, a portfólióhangolás kommunikáci- 
ója. A Project Management Institute (PMI, 2011) értelmezésében a portfóliókockázat-menedzsment feladatai közé tartozik a portfóliókockázatok azonosítása, elemzése, kezelésük kidolgozása, valamint a portfóliókockázatok követése és felügyelete is.

Az ISO - elismert szabvány - kisebb terjedelemben, de hasonlóképpen írja le a portfóliómenedzsment feladatát, mint a PMI kiadványa. Azzal a meggondolással él, hogy ahhoz, hogy hatékonyan építsünk fel egy portfóliót, a portfólió elemeit folyamatosan azonosítanunk, értékelnünk, kiválasztanunk, engedélyeztetnünk kell, és a portfólió teljesítményéröl folyamatosan jelentenünk kell. Továbbá az is szükséges, hogy folyamatosan hozzáigazítsuk a portfóliót az üzleti és stratégiai célokhoz, valamint a portfólió-egyensúly biztosításához fenn kell tartani egy több kritérium szerinti értékelő rendszert is (ISO, 2015).

\section{Gyakorlati tapasztalatok}

A PPM-mel kapcsolatos tapasztalatokról ma már könnyen tájékozódhatunk. Ilyen célra rendelkezésünkre állnak tudományos közlemények csakúgy, mint a szakmai szervezetek/tanácsadó cégek felmérései. Ezek a portfóliómenedzsment számos aspektusát érintik, például Meskendahl több cikkében is a projektportfólió sikerességével foglalkozik (Meskendahl, 2010; Meskendahl et al., 2011). 2011-es cikkében szerzőtársaival, egy 2003 óta zajló vizsgálatsorozatból a 2009-est mutatták be, ahol az elemzés egyik fő célja az volt, hogy megtudják, milyen tényezők járulnak hozzá a portfólió, illetve a vállalat sikerességéhez. Ahhoz, hogy jobban el tudják különíteni a vállalatokat az eredményük alapján, 3 csoportba sorolták őket: top 20\%, low 20\% és az átlag. A négy tényező, ami mentén tovább vizsgálták a vállalatokat az alábbiak voltak: szerepek, stratégiai szint, taktikai szint, operatív szint. (Szerepek alatt a vállalaton belüli, illetve a projektportfólión belüli szerepek definícióját kell érteni. Fontos, hogy egy projekt esetén a résztvevők tisztában legyenek azzal, hogy mi a szerepük, és mi a feladatuk a megvalósításban.) Alapvetően a top vállalatok a kevésbé sikeres vállalatoktól abban különböztek, hogy a szerepek minden résztvevő számára ismertek és jól definiáltak voltak. A stratégiát a stabilitás és az alapos elemzés jellemezte. Fontos továbbá, hogy azok a vállalatok, amelyeknél a stratégiai tervezés konzultációt követően, közös megegyezéssel készült el, jobb eredményt értek el, mint a többi vállalat. A kutatásból az is kiderül, hogy azok $a$ vállalatok, amelyek sikeresek a projektportfólió megfelelö irányitásában, azok összességükben is sikeresebbek az átlagnál. A sikerrel kapcsolatban Müller et al. (2008) átfogó statisztikai elemzésük alapján a következő megállapításokat tették: a sikeres szervezetek szervezeti szintü gyakorlattal rendelkeznek a projektek stratégiának megfelelö, szelektálásával és priorizálásával kapcsolatban. Formalizált jelentéstételi mechanizmusuk van a projekt és a portfólió közötti információáramlás megkönnyítésére, valamint a felelősségek megosztása portfólió szinten történik. A különféle kontrollmechanizmusok a portfóliósiker más aspektusára hatnak kedvezően. Ennek megfelelően a beszámolási rendszer elsősorban az elsődleges projektcélok elérését szolgálja, míg a megfelelő projektek kiválasztása és portfólióba rendezése - nem meglepő módon - a szervezet stratégiai törekvéseihez járul hozzá.

Martinsuo (2013) írásában a projektportfólió-menedzsmenttel kapcsolatos új empirikus kutatások eredményeit elemzi. Ö már a tapasztalatok alapján a PPM racionális döntéshozatali folyamatként történő értelmezésének korlátjaira hívja fel a figyelmet. Rávilágít arra, hogy a PPM-folyamat a gyakorlatban, a klasszikus megközelítéssel szemben, nem a vállalat stratégiai célkitűzéseit támogató racionális döntéshozatali processzus, hanem sokkal inkább emberek és szervezetek között végbemenö interakciók sorozata. E kölcsönhatások erősen személyfüggők és kihathatnak az érintett szervezetek struktúrájára is.

Korlátai ellenére a PPM mindenképpen egy új stratégiai menedzsmenteszköznek tekinthető, amely természetesen nemcsak a hosszú távú stratégiai célok elérésében segít, hanem sokkal rövidebb távon is kifejti hatását, illetve a vállalat életében "krónikus vagy akut" problémákat is orvosolhat. Hiszen a PPM-megoldások használatához is leginkább oly módon jutnak el a szervezetek, hogy vezetőik érzékelik a sok projekt együttes kezeléséből adódó problémákat. Leegyszerüsítve a következő problémacsoportról van szó: A projektek nagyrészt nem sikeresek, időben csúsznak vagy túllépik költségkeretüket. Az imént ismertetett tudományos tapasztalatok mellett - praktikus megfontolásokból - ezekkel a negatív jelenségekkel és konkrét adatokkal találkozhatunk a nagyobb tanácsadó cégek és szakmai szervezetek (pl. PMI, PricewaterhouseCoopers - PwC, Gartner, UMT) felméréseiben. Ez az interpretáció azonban jól rávilágít a mindennapi szervezeti müködésben felmerülő probléma súlyosságára.

A témába vágó nemzetközi kutatási jelentések közül a PMI Pulse of the Profession (PMI, 2012), majd a PwC Insights and Trends (PwC, 2012) felméréseinek néhány adatára hivatkoznék. ${ }^{5}$ Az első felmérésböl többek között megtudhatjuk, hogy azoknál a cégeknél, ahol valamilyen szintü projektportfólió-menedzsment gyakorlat már létezik, ott is csak a projektek felét sikerül időben befejezni (50\%-ban nem), a költségkeretet pedig csak 54\%-ban sikerül tartani (46 \%-ban nem). A fejlett PPM-módszertannal rendelkező szervezetek esetében ezek az értékek rendre 10-18\%-kal jobb szintü teljesítést mutatnak, mint a kevésbé fejletteknél. A hozamelvárásokban a fejlett módszertannal rendelkező szervezeteknél a projektek $62 \%$-a elérte vagy túlszárnyalta a befektetések várt megtérülését (ROI, return on investement), míg a már említett - ilyen

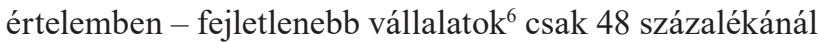
sikerül elérni ezt a pénzügyi célkitüzést (tehát 52\%-nál nem). Mindezt lásd a 2. ábrán.

Ezeknek az adatoknak az értelmezésénél azonban külön felhívnám a figyelmet arra, hogy a föleg nemzetközi nagyvállalati körben lezajlott kutatások eredményei természetszerüleg torzított képet mutatnak a valóságról. Mindenesetre a PwC felmérésében a vállalatok 53\%-a használ PPM-et. Így a hivatkozott a nem-sikerességet jelző adatok (időtúllépés, költségtúllépés, pénzügyi és üzleti célok elvétése) az összes sok projektet kezelő vállalat esetében a fentiekhez képest jóval rosszabb képet mutathatnak. 
Az időtúllépéssel, költségtúllépéssel stb. jellemezhető helyzetek bekövetkezésének sok esetben könnyen elkerülhető okai vannak. Hiszen azok a tényezők, amelyek ide vezetnek, gyakran már a koncepcióalkotási, illetve a tervezési fázisban könnyen azonosíthatóak, ebből adódóan elkerülhetők. (Persze nemcsak a projektindítás előtti szakaszban van mód beavatkozni, a módszer ugyanis lehetöséget nyújt a már megvalósítási szakaszukban járó projektek kezelésére is.) Egy megfelelő vállalati PPM-folyamat bevezetésével/alkalmazásával az előzőekben említett, vagy az ahhoz hasonló, gyenge eredmények jelentősen javíthatók. Mindezekröl a javulásokról leginkább szakértői beszámolókból értesülhetünk, mivel - természetszerülegaz ilyen jellegü, érzékeny céges adatok nemigen kerülnek napvilágra. A beszámolókból azonban bizton tudhatjuk, hogy a javulás akár szignifikáns költségcsökkenés, illetve hatékonyságjavulás formájában is mérhető.

Mindenesetre az eddigiekben hivatkozott kutatási jelentések jól alátámasztják azt az egyszerü összefüggést, hogy minél jobb a szervezeti PPM-gyakorlat, annál eredményesebbek a projektek (lásd ugyanezt PMI, 2012, p. 9. megfogalmazásában). Különösen igaz ez a mai rohanó üzleti világban, ahol a siker gyakran a lehetőségek és a hozzájuk füződő kockázatok nehezen megragadható egyensúlyának megértésén múlik. A projektek és programok mennyiségének, szolgáltatási körének, költségvetési számainak növekedésével ez egyre komplexebb feladatot jelent. Ennek megfelelően a felső vezetők közül sokan kezdik felismerni, hogy az egyik leghatékonyabb módja annak, hogy szervezetük számára a projektek és programok biztosítani tudják az elvárt előnyöket, az a projektportfólió-menedzsment megoldások alkalmazása. Ezt mutatja a PMI (Pulse of the Profession) 2012-es felmérése is, amelyben a válaszadók több mint fele arról számolt be, hogy szervezetükben a projektportfólió-menedzsmentet gyakran használják. (Ez a több mint 50\%-os arány a saját korábbi felmérésükhöz képest érzékelhető előrelépést mutat.) ség, terjedelem, a projektek ütemezésének egyszerüsödése, és ezeken túl a piaci részesedés és a bevételek növelése is megjelenik a felmérésekben, mint elérendő cél.

A módszer iparági elterjedtségével kapcsolatban a PwC 2012-es felméréséből azt is tudhatjuk, hogy a PPMet használó szervezetek között a legmagasabb használati arányt a kiskereskedelemben, a biztositás, az autó-, a bank- és töke-piacon, valamint a telekommunikáció, a gyártás, illetve az energia és védelmi politika piacán müködő vállalatok mutatják.

Magyarországon csakúgy, mint külföldön elsőként a multinacionális nagyvállalatoknál és a nagy közmüszolgáltatók esetében vezettek be PPM-megoldásokat. Ezeknek a megoldásoknak a bevezetése, olykor összekapcsolódott - piaci beszerzésű - PPM-támogató szoftverek bevezetésével is. A menedzsmentfejlesztés azonban nem feltétlenül jár együtt sikeres szoftverbevezetéssel, hiszen saját fejlesztésü szoftverekkel is találkozhatunk, vagy éppen némi használati idő után szoftverkivezetésekre is akad példa.

A korai bevezetőkkel kapcsolatban továbbá azt is meg kell említeni, hogy a nagyvállalati és iparági jellegen túl nyilvánvalóan meghatározó a gazdálkodás szervezeti kontextusa is. Azaz más-más jelleggel, de nyilvánvalóan a projektorientált és a projektalapú szervezetek (Görög, 2013) azok, amelyek élenjárnak az új menedzsmentmódszer alkalmazásában.

Szakirodalmi és piaci információk alapján, a teljesség igénye nélkül néhány ismertebb magyar példa a korai bevezetők közül. A gépjármüipar területéről: Audi, Mercedes, evopro, a telekommunikációs szektorból: Telekom, Telenor, Vodafone, az állam-szolgáltatás-közmü-energetika területéröl: MVM, MNB, NAV, EON, MP, Lufthansa, MOL. A biztosítók közül: NN, Generali, a high tech- és szoftver-iparból: Ericsson, NavNGo. A korai magyar PPM-alkalmazók elsődleges tapasztalatai közül, a továbbiakban a bankszektorból származóakról írok majd. Ennek egyik oka, hogy a külföldi tapasztalatokkal megegyezően (ld.

\section{A portfóliómenedzsment hatása a projektjellemzőkre}

\begin{tabular}{lccc} 
& Magas hatékonyságú PPM & Alacsony hatékonyságú PPM & Növekedés (\%) \\
\hline A PROJEKTEK ÁTLAGOS SZÁZALÉKA: & & $50 \%$ & $36 \%$ \\
\hline Befejeződött határidőre & $68 \%$ & $54 \%$ & $19 \%$ \\
Költségkereten belül került végrehajtásra & $64 \%$ & $65 \%$ & $18 \%$ \\
Elérte az elvárt üzleti célokat & $77 \%$ & $48 \%$ & $29 \%$ \\
Elérte/meghaladta az elvárt ROI-t & $62 \%$ &
\end{tabular}

Forrás: Project Management Institute, Inc. Pulse of the Profession ${ }^{\text {TM }}$ In-Depth Report: Portfolio Management, November 2012. PMI.org/Pulse

Ha túllépünk a hatékonyság (hatékonytalanság) és siker kardinális kérdésén, akkor a felmérésekből arra is választ kaphatunk, hogy a vállalatok milyen (részcélok) mutatók javításának az érdekében kezdik el használni a PPM-et. Eszerint a következő kulcs teljesítménymutatókban jelenik meg a javulás: üzleti előnyök, minőség, költ- korábban a PwC 2012-es felmérésében) a PPM szempontjából a szektorra, Magyarországon is kiemelt területként figyelhetünk. Ebből a magyar viszonylatban „,fejlettebb” banki PPM-kultúrából adódik, hogy szakértői, menedzseri szinten már rendelkezésre állnak, illetve ezen túl el is érhetőek bizonyos információk, tapasztalatok. 
A szektor elmúlt időszakával kapcsolatban általánosan elmondható, hogy az utóbbi években a banküzletet komoly kihívások érték, akár a 2008-as pénzügyi válságra és következményeire gondolunk, akár a devizahitelezésből adódó problémákra. Mindezek a kihívások nagy hatással voltak a banki müködésre.

A magyar tapasztalatok ismertetése elött a nemzetközi és hazai helyzettel kapcsolatban leszögezhetjük, hogy a 2008-as válság a bankszektort igen súlyosan érintette. Magyarországon további problémát okozott a bankoknak az is, hogy az állami szabályozásból adódóan, a szektor szereplőinek további terheket kellett vállalniuk (pl. elszámoltatás és devizahitelezés megszüntetése). Ezzel összecsengenek Bruck (2009) nemzetközi tapasztalatai, miszerint a 2008-as banki válsággal kapcsolatban elmondható, hogy kitörése után, illetve a problémák ellenére, a szektorban a PM-kultúra egészséges. Ebben az időben a projekt-, program- és portfólió-menedzserek szerint a fó változások és kihívások közé tartozik az információs technológia (továbbiakban IT) fejlődése és szerepének folyamatos növekedése, a globalizáció erősödése, illetve a pénzügyi szektorban a verseny erősödése. Az IT-val kapcsolatos projektek gyarapodnak és a projektek IT igénye is nő. Ez az általánosnak mondható vélekedés - a piaci információk alapján is - a válság óta folyamatosan igazoltnak tünik.

A külföldi bankok a projekt-, program- és portfóliómenedzsment módszertan bevezetésére és fejlesztésére vonatkozó gyakorlatát leginkább szakértői beszámolókból ismerhetjük. Az esetleírásoknak nevezhető publikációk, különböző vizsgálati fókusszal és mélységben foglalkoznak a témával. Ilyen pl. Nieto (2010) tanulmánya, amely a Fortis bank BNP Paribas-ba olvadásának példáját elemzi, de megemlíthető Hoffmann - Rentrop (2012) szerzőpáros munkája is, amely egy bank projektrangsorlási módszertanának fejlődését mutatja be. Természetesen más egyedi esetleírások is említhetőek lennének, de ezek sajnos nem jelentenek még igazi összehasonlítási alapot a magyar bankokkal kapcsolatban. Speciális helyzetéből adódóan, korlátozott, az egyik figyelemreméltó magyar vonatkozású (MNB-s) esetleírás (Pap, 2010) ilyen célú használata is.

\section{A magyar banki gyakorlat}

A magyar tapasztalatok hat „,pozícióban lévő” - vagy onnan éppen eltávozott - banki portfóliómenedzserrel készített interjú alapján fogalmazódtak meg. ${ }^{7}$ A továbbiakban, az ezekben az interjúkban feltárt témák legfontosabb elemeit összegzem. Ezzel kapcsolatban fontos kiemelni, hogy az új menedzsmentmódszer megjelenésének tapasztalatai mellett, természetszerüleg sok bankszférát jellemző információt ismertetek. Az itt közölt tapasztalatok egyféle kutatási jelentésként foghatók fel (részletes elemzésekre jelen cikkben nem vállalkozom). Mindenesetre az interjúkban érintett hat jelentős magyarországi bank példája egyféle elsődleges mélyebb hazai tapasztalat leírásának is tekinthető. A hat jelentős magyar lakossági bank szinte kiteszi a teljes sokaságát a hazánkban nagy lakossági bankként - nyolc ilyen bankot tartunk számon - elkönyvelt vállalatoknak.
Az itt hivatkozott kisléptékü kutatás egyrészt felmérte a hazai bankokban a projektkultúra fejlettségét és a PPM-módszertan alapismertségét. Másrészt arra kereste a választ, hogy milyen módon valósulhat meg a PPM bevezetése egy bankban és annak alkalmazása során milyen, a szektorra jellemző specifikumokat kell kezelni. Minderre strukturált, kb. 20-30 perces interjúk adtak lehetőséget. Az interjú kérdései a következő területekre vonatkoztak: piaci viszonyok és kihívások, legnagyobb projektek és programok, a PPM-módszertan bevezetése, a projektportfólió-menedzsment szervezete, PPM és funkcionális területek, a szervezet projektkultúrája, szoftverek, PPM-folyamat, jövőbeli várakozások.

Az interjúkban elhangzott vélemények, kérdéskörönkénti feldolgozása után a következő összegző tapasztalatokról számolhatok be.

A bankok 2006 és 2012 között vezették be a portfóliómenedzsment módszerét. A bevezetés kezdeményezése, szervezeti szerepüktől függően, igen különböző személyektől indult. A megkérdezettek egyik fő meglátása a kérdéssel kapcsolatban az volt, hogy a PPM bevezetéséhez nélkülözhetetlen a felső vezetés támogatása. További fö tapasztalatként az is kiemelhetö, hogy az esetek többségében a portfólió-menedzserek megjelenését projektmenedzsment iroda (PMO) müködtetése előzte meg, illetve alapvetően az IT-projektek kapcsán, pontosabban az ilyen projektek számának növekedése miatt vált egyre szükségesebbé a módszer bevezetése.

Abban is több interjúalany egyetértett, hogy az adott szervezetet jellemző projektkultúra, annak fejlettsége, illetve a PPM-módszertan gyakorlati alkalmazásának mikéntje, igencsak személyfüggő, azaz nagyban függ az aktuális projekt-, program-, portfóliómenedzserek előéletétől, vezetői képességeitől, szakmai felkészültségétől, személyiségétöl stb. Ehhez kapcsolódik, hogy többen szót ejtettek a szakterületen érzékelhető fluktuációról is. A portfóliómenedzserek - illetve a feladatot felügyelő vezető - cseréjével természetszerüleg megjelentek új megközelítések és eszközök. Ezek az újítások összefüggenek a PPM módszerének folyamatos fejlődésével, illetve a már említett személyi tényezőkkel is. Ilyenkor elsődlegesen olyan egyszerübb változásokra lehet gondolni, mint például a projektfüggőségek feltárására, kezelésére törekvés megerősödése, vagy a projekttag szintü jelenléti ívek bevezetésére.

A banki válaszadók mindegyike fejlettnek tekintette saját bankjának projektkultúráját. Ezt a projektmenedzsment formalizáltságával, a projektszervezet és az üzleti területek közötti konfliktusok hiányával, a belső kommunikáció hatékonyságával, a projektszervezeten kívüli érintettek projektekkel kapcsolatos tájékozottságával indokolták. Azonban az utóbbi, valamint a projekt- és a portfóliómenedzsment elismertsége szakterületek szerint azért változó. Vannak olyan banki szakterültek, amelyek a PPM-mel megjelenő változásokat könnyebben el tudják fogadni, de vannak olyanok is, melyek esetében külön támogatást igényel az ilyen változások elfogadtatása. Az olyan bankoknál, melyeknél az informális kapcsolatoknak különösen hangsúlyos a jelentőségük, kiemelt szerepet 
játszhat például a portfóliómenedzser szervezeten belül kiépített kapcsolati hálója is (bizalmi kapcsolatai, bejáratott ügyintézési praktikái stb.). Volt olyan banki eset, ahol sokat segített a PPM elismertségében a portfóliómenedzser személyes részvétele egy-egy projekt végrehajtása során.

A piaci trendeket követve és a jogi környezet elvárásainak megfelelve, a projektek, programok és egyéb munkák nagy része a digitalizációhoz, illetve a törvényi megfeleléshez köthető. Utóbbiak mind a hazai, mind az európai uniós jogszabályi elöírásoknak való megfelelésre vonatkoznak (továbbá egy amerikai iparági szereplő esetén az amerikai jogszabályokat is figyelembe kellett venni). Minden megkérdezett bankban óriási kihívásként élték meg, hogy habár elöre tudtak egy-egy jogszabályi változásról, a részletek megjelenésétől az implementálási határidőig megadott időintervallum nagyon szűk volt. Ehhez alkalmazkodva például az egyik bank mára már külön tartalékot határoz meg, mindemellett a várható erőforrásigény becslése továbbra is nehéz feladat. További probléma, hogy a szükös erőforrásokkal rendelkező bankoknál a törvényi megfelelési projektek forrást vonhatnak el az üzletfejlesztési projektektől, ezzel azonban a szervezet fenntartható jövedelmezősége kerülhet veszélybe. Egy másik banknál ennek elkerülésére magas szintü erőforrás-menedzsmentet alkalmaznak. Az erőforrás-probléma kezelésére, az elsőnek említett bank esetében, a megoldást az jelenti, hogy a portfóliómenedzserek mindenkor erősen törekszenek a minimum „scope” betartatására. Mindezen erőfeszítések ellenére, például a devizahitelek forintosítása minden megkérdezett bank esetében projektek felfüggesztésével járt együtt. Egy harmadik banki válaszadó ezzel a kérdéskörrel kapcsolatban kifejtette, hogy a következő egy-két évben, a hazai törvényi rendelkezések miatti erőforrásigény már kisebb lesz és a kapcsolódó projektek mérete is csökkeni fog. Ugyanakkor - véleménye szerint ebben az időszakban, inkább a nemzetközi törvényi megfelelési projektek fognak majd dominálni.

A másik környezeti tényező, mely a portfóliókomponensek jelentős hányadát életre hívta: a digitalizáció. Ez általában a honlapot, az internetes banki szolgáltatásokat és a mobilbankolást foglalja magába. Az online banki szolgáltatások térnyerése a fiókhálózat leépítésével járhat együtt. Azonban a bankoknak figyelniük kell, e projektek kapcsán, az automatizáltság mértékére, hiszen az ügyfelek egy része még mindig igényli a személyes megjelenést. Ebből a szempontból is kiemelt figyelmet kell fordítani a jogi szabályozásra, hiszen hazánkban, ez jellemzően a szokásosnál nagyobb mértékben terjed ki a fiókhálózatokra. Itt kell megemlíteni még a bankszektor számára legnagyobb kihívást jelentő újdonságot, az ún. Fintech cégek megjelenését. Az egyik válaszadó megfogalmazása szerint: ezek az új, „start-up stílusú versenytársak rákényszerítik a bankokat az ötletelésre, az új irányok keresésére", ami természetszerüleg lecsapódik a projektek szintjén is.

A PPM-funkció szervezeti megjelenését vizsgálva, egyik megkérdezett bank sem tekinthető ugyanolyannak. ${ }^{8}$ Különböznek többek között a portfóliómenedzserek számában, a PPM-terület szervezeti struktúrában való elhelyezkedésében, a PPM-folyamatok szereplőinek megnevezésében, vagy a funkcionális területekkel történő együttmüködés szorosságában. A nagyságrendeket érzékeltetve: jellemző azért az egy PPM-tevékenységért felelős személy, illetve az 1-3 portfóliómenedzser - a hozzájuk tartozó 1-3 (rész)portfólióval - jelenléte, olykor a két szint felelősségi-munkaköri átfedésével együtt értendően. Szervezetileg jellemzően a PMO az, amely a portfóliómenedzsment funkciót ellátja. A PPMO szervezeti egységek, tehát nem jelentek még meg a gyakorlatban (bár egy esetben már erről is beszélhetünk). Ha a szervezeti elhelyezkedés kérdését tekintjük, a vélemények alapján megfogalmazható az a közkeletü - de a szakirodalomból is ismert - igény, hogy a PPM-szervezetnek a funkcionális területektől elkülönülten, minél magasabb hierarchiaszinten kellene megjelennie. Ezáltal, a más területektől való függetlenség biztosításának köszönhetően, minimalizálható a projektek kiválasztása, priorizálása során fellépő a funkcionális területek általi - befolyásolhatóság.

Ha a PPM-folyamatokat módszertani szempontból vizsgáljuk, elmondható, hogy a bankok többsége esetében az egyik kezdeti lépéseként ismert komponens (projekt) kategorizálás megtörténhet részportfóliók, méret szerint, illetve a szerint, hogy csoport szintü-e, kötelezően végrehajtandó-e vagy sem az adott projekt. Ezek a kategóriák egyébként átfedésben is lehetnek egymással (a már többször említett kettősség, egyébként leképeződik a gyakran használt törvényi és egyéb kategóriázásban is). A komponensek érékelése, kiválasztása, priorizálása, kiegyensúlyozása, engedélyezése, monitoringja lépésekre vonatkozóan a bankok eltérő eszközöket, módszereket, technikákat alkalmaznak (természetesen a megtérülés-számítás azért mindenhol jelen van). A komponensekkel kapcsolatos végső döntést (portfólióba kerülés, leállítás, felfüggesztés) általában testületi szürés (egyféle alkufolyamat) után, egy felső vezető hozza meg. A megkérdezett bankok mindegyike törekszik a megfelelő projektek kiválasztására annak érdekében, hogy a későbbiek során ne kelljen leállítani egy projektet sem. Ha erre mégis sor kerülne, akkor az a beszámolók szerint, föként a környezeti változások miatt szükséges.

A PPM szoftveres támogatásában a vizsgált bankok fóként az Excelre támaszkodnak. Saját fejlesztésü PPM-szoftvert, annak erőforrás igénye miatt nem alkalmaznak. A piacon elérhetöeket pedig nem lehet a szervezeti igényeknek megfelelően testre szabni. Bár egy-két vezető PPM-szoftvert, amellyel már így-úgy kapcsolatba kerültek, azért megemlítettek a válaszadók (például: CA, HP). További PPM-et támogató, megemlített szoftver a SharePoint, a Microsoft Project és a Lotus Notes (természetesen erre a célra használva).

\section{Összegzés}

A következőkben elméleti felvetéseimet és gyakorlati tapasztalatgyüjtésemet röviden összegzem. A tanulmány elején értelmeztem a PPM problematikáját, bemutattam koncepcióját, illetve feladatrendszerének lényegi elemeit. A nemzetközi felmérések alapján, müködésének, ter- 
jedésének, hatékonyságának elemeiről írtam. A módszer magyarországi gyakorlati megvalósulásával kapcsolatban egy feltáró jellegű primer kutatás legfontosabb megállapításait ismertettem.

Eszerint a hazai bankszektort érintő piaci kihívásokra adott reakcióként, illetve a lehetőségek kihasználása érdekében indított projektek jellegét tekintve, egyértelmü egyetértés mutatkozik a bankok között. A projektek, programok és egyéb munkák nagy arányban a digitalizációhoz, illetve a törvényi megfeleléshez köthetők. Mindegyik vizsgált bank már rendelkezik egy formalizált projektmenedzsment-módszertannal. Azonban a PPM-módszertan alkalmazásában igen sokszínűek mind a szervezeti struktúrában való elhelyezkedést, mind a PPM struktúráját tekintve. További tapasztalat, hogy a módszer alkalmazása kapcsán problémás területként jelenik meg: a projektfüggöségek kezelése, az erőforrás-tervezés mélysége vagy a PPM-struktúra szereplöinek elfogadottsága az üzleti területek által.

Az elméleti és gyakorlati megfontolások alapján számos kutatási témakör jelölhető ki. Ezek közül megnevezném a PPM gyakorlati megvalósítása során fellépő szervezeti konfliktus teljes körü elemzését, vagy a különböző iparágakra, illetve szervezeti típusokra (pl. projektorientált, projektalapú) irányuló kutatásokat.

\section{Jegyzet}

1 A PPM stratégiai megközelítését szinte kizárólag a nemzetközi szakirodalomból (pl. Rajegopal et al., 2007) ismerhetjük.

2 Ebben a szemléletben íródott a már hivatkozott, Sebestyén 2009-es és Sebestyén - Tóth 2012-es cikke is.

3 Ilyennek tekinthető a brit AXELOS: Management of Portfolios kiadványa is.

4 Rangsorolás gyakran használt idegen szóval: priorizálás.

5 PMI Pulse of the Profession felmérésének mintája 443 vállalatot (portfóliómenedzsert) tartalmazott, míg a PwC Insights and Trends felmérése 1624 elemü mintán készült.

6 A felmérésekben egyébként gyakran találkozhatunk felkészültség, érettség szerinti kategorizálással. Ilyen a PROJECT MANAGEMENT SOLUTIONS 2013-as felmérése is, amelyben a közel 500 megkérdezett vállalatot a kutatók öt kategóriába soroltak PPM-képességük (PPM capability) alapján.

7 Az interjúk 2015 őszén és 2016 tavaszán készültek.

8 Annyi azért ezzel kapcsolatban kijelenthetö, hogy a mai napig fennálló IT-orientáltság, a kezdeti időkben, mindenképpen nagy hatással volt a PMO szervezeti elhelyezkedésére.

\section{Felhasznált irodalom}

Beringer, C. - Jonas, D. - Kock, A. (2013): Behavior of internal stakeholders in project portfolio management and its impact on success. International Journal of Project Management, Volume 31, Issue 6, August, p. 830-846.

Blichfeldt, B. S. - Eskerod, P. (2008): Project Portfolio Management - There's More to it than What Management Enacts. International Journal of Project Management, 26(4), p. 357-365.

Bruck, H. (2009): Challenge of Managing Financial Services Projects. in: Project Management Circa 2025. Podcast. Pennsylvania: Project Management Institute Inc.

Chao, R. O. - Kavadias, S. (2008): A theoretical framework for managing the new product development portfolio: when and how to use strategic buckets. Management
Science, 54 (5), p. 907-921.

Devinney, T. M. - Stewart, D. W. (1988): Rethinking the product portfolio: A generalized investment model. Management Science, 34, p. 1080-1095.

Dye, L. D. - Pennypacker, J. S. (eds.) (1999): Project Portfolio Management: Selecting and Prioritizing Projects for Competitive Advantage. West Chester, PA.: Center for Business Practices

Gareis, R. (2007): Projekt? Örömmel!: Projekt- és programmenedzsment, projektportfólió-menedzsment, projektorientált szervezetek menedzselése: Új elméletek, modellek, gyakorlati alkalmazások, esettanulmányok. Budapest: HVG Zrt.

Görög M. (2013): Projektvezetés a szervezetekben. Budapest: Taramix Könyvkiadó/PANEM Könyvek

Hoffmann, O. - Rentrop, Ch. (2012): Priorisierung von Projekten. Zeitschrift Führung und Organisation, Vol. 81 Issue 1, p. 23-28.

ISO (2015): ISO 21504:2015: Project, programme and portfolio management - Guidance on portfolio management. ISO

Jonas, D. (2010): Empowering project portfolio managers: How management involvement impacts project portfolio management performance. International Journal of Project Management, 28(8), p. 818-831.

Levine, H. A. (2005): Project Portfolio Management. San Francisco: Jossey-Bass

Ligetvári Éva (2013): A minőség megjelenése a projektportfólió-menedzsmentben. Minőség és Megbizhatóság, 46:(4), p. 176-181.

Ligetvári Éva (2012): Projektportfólió-menedzsment, avagy hogyan választunk téglát az építkezés során. in: Svéhlik Csaba (szerk.): VII. KHEOPS Tudományos Konferencia: ,Aktuális gazdasági és társadalmi attitüdök Magyarországon”. 318 p. Konferencia helye, ideje: Mór, Magyarország, 2012.05.16. Mór: Kheops Automobil-Kutató Intézet, 2012. p. 63-68.

Martinsuo, M. (2013): Project portfolio management in practice and in context, International Journal of Project Management, Vol. 31 No. 6, p. 794-803.

Meskendahl, S. (2010): The influence of business strategy on project portfolio management and its success - a conceptual framework. International Journal of Project Management, 28(8), p. 807-817.

Meskendahl, S. - Jonas, D. - Kock, A. - Gemünden, H. G. (2011): Wie Untermnehmes erfolgreich ihr Projektportfolio managen - Ergebnisse der 4. Studie zum Multiprojektmanagement der TU Berlin. Projekt Management, 2011/1, p. 20-25.

MoP (2011): Management of Portfolios. Norwich: TSO

Morris, P. W. G.- Jamieson, A. (2005): Moving from corporate strategy to project strategy. Project Management Journal, 36 (4), p. 5-18.

Nieto, A. (2010): BNP Paribas Fortis, Brussels, Belgium. http://www.pmi.org/learning/merger-failure-organization-lessons-learned-3877

Pap Gyula (2010): Projektportfólió-menedzsment a Magyar Nemzeti Bankban. Projektmenedzsment, LXV. évfolyam 2010/7-8. szám, p. 38-41. 
Petit, Y. - Hobbs, B. (2010): Project portfolios in dynamic environments: sources of uncertainty and sensing mechanisms. Project Management Journal, 41(4), p. 46-58.

PMI (2011): Projektportfólió-menedzsment. Budapest: Akadémiai Kiadó

PMI (2012): Pulse of the Profession In-Depth Report: Portfolio Management, Newton Square, PA.: Project Management Institute Inc.

PMI (2013): Projektmenedzsment útmutató. Budapest: Akadémiai Kiadó

Project Managemet Solutions (2013): The State of Project Portfolio Management. Glen Mills. http://www.pmsolutions.com/reports/State_of_PPM_2013_Research_Report.pdf

$P w C$ (2012): Insights and Trends: Current Portfolio, Program, and Project Management Practices. London: PwC

Rajegopal, S. - McGuin, P. - Waller, J. (2007): Project Portfolio Management: Leading the Corporate Vision. Basingstoke: Palgrave Macmillan

Müller, R. - Martinsuo, M. - Blomquist, T. (2008): Project Portfolio Control and Portfolio Management Per- formance in Different Contexts. Project Management Journal, Vol. 39, No. 3, p. 28-42.

Rouwendaal, J. V. - Donselaar, J. W. - Weeghel, M. V. (2014): Project Portfolio Management Office (PPMO). http://flourish.nu/?p=159

Sebes József (2013): Stratégia - projekt - beruházás controlling kapcsolata és összefüggései. Budapest: Aura Kiadó

Sebestyén Z. (2009): Válasz a legújabb kihívásokra: projektportfólió-menedzsment Vezetéstudomány, XL:(külön.), p. 74-78.

Sebestyén Z. - Tóth T. (2012): Modellalkotás a projektportfólió-menedzsmentben. Marketing és Menedzsment, 46:(1), p. 148-157.

Unger, B. N. - Gemünden, H. G. - Aubry, M. (2012): The three roles of a project portfolio management office: Their impact on portfolio management execution and success. International Journal of Project Management, Vol. 07, No. 5(30), p. 608-620.

Zdanyte, K. - Neverauskas, B. (2011): The theoretical substation of project management challenges. Economics \& Management, 2011, Vol 16, p. 1013-1018. 